\title{
Human-wildlife conflict and community perceptions towards wildlife conservation in and around Wof- Washa Natural State Forest, Ethiopia: a case study of human grivet monkey conflict
}

Dereje Yazezew ( $\sim$ deredbu2003@gmail.com )

Debre Berhan University

\section{Research Article}

Keywords: Crop damage, Grivet monkey, Human-wildlife conflict, Local communities, Questionnaire survey, Respondents perceptions

Posted Date: December 23rd, 2021

DOI: https://doi.org/10.21203/rs.3.rs-1001104/v1

License: (c) (1) This work is licensed under a Creative Commons Attribution 4.0 International License. Read Full License 


\section{Abstract}

Background: Human-wildlife conflict (HWC) is predicted to increase globally in the vicinity of protected areas and occurs in several different contexts and involves a range of animal taxonomic groups whose needs and requirements overlap with humans. Human-monkey conflict exists in different forms more in developing countries and ranks amongst the main threats to biodiversity conservation. Grivet monkeys (Cercopithecus aethiops aethiops) are any slender agile Old-World monkeys of the genus Cercopithecus. This study was conducted to investigate the status of human grivet monkey conflict and the attitude of local communities towards grivet monkey conservation in and around Wof-Washa Natural State Forest (WWNSF), Ethiopia from September 2017 to May 2018. Questionnaire survey (143) was used to study the human-grivet monkey conflict and its conservation status. Data were analyzed using descriptive statistics and the responses were compared using a nonparametric Pearson chi-square test.

Results: Majority of respondents from both gender (male= $67.1 \%$; female= $74.1 \%$ ) were not supporting grivet monkey conservation due to its troublesome crop damaging effect. There was significant difference in respondents perceptions towards grivet monkey conservation based on distance of farmland from the forest $(\chi 2=12.7, d f=4, P=0.013)$. There was no significant difference in the techniques used by villagers to deter crop raiders $(X 2=14.73, d f=15, P=0.47)$. There was significant difference in respondents expectations on the mitigation measures to be taken by government $\left(\chi^{2}=\right.$ $40.01, \mathrm{df}=15, \mathrm{P}=0.000)$. Based on the questionnaire result, $42.5 \pm \mathrm{SD} 8.68$ of respondents in all villages elucidated that the causes of crop damage was habitat degradations.

Conclusion: The encroachment of local communities in to the forest area and exploitation of resources that would be used by grivet monkey and enhanced crop damage by grivet monkey exacerbated the HGMC in the study area. As a result grivet monkeys have been killed relentlessly as a consequence of crop damage. This was due to negative energy developed in human perspective. Thus, awareness creation education program and feasible crop damage prevention techniques need to be implemented.

\section{Introduction}

Human-wildlife conflict (HWC) is predicted to increase globally and occurs in several different contexts and spans a range of animal taxonomic groups[1, 2]. Currently, HWC is a global issue that has adverse consequences for both humans and wildlife [3]. Human Wildlife Conflict (HWC) arises from a range of direct and indirect negative interactions between humans and wildlife. This occurs when the needs and requirements of human and wildlife overlap, which usually results in costs to both the local residents and animals when the needs of one impact negatively on the other $[1,4]$. The loss, degradation and fragmentation of habitats through human activities such as, logging, animal husbandry, agricultural expansion and developmental projects [5-7] intensify the conflict. Ecosystems and habitats alarmingly dominated by humans, which trigger species including primates compelled to exploit new human resources to survive $[8,9]$. As habitat is fragmented, the length of edge for the interface between humans and wildlife increases, while the animal populations become compressed in limited refuges. 
Consequently, it leads to greater contact and conflict with humans as wild animals seek to fulfill their nutritional, ecological and behavioral needs [10]. These can culminate in potential harm to all participants, and lead to negative human attitudes, with diminished appreciation of wildlife and severe detrimental effects for conservation.

Human activities like logging, deforestation, hunting, agricultural expansion, and other such factors intensely affected primate populations [11]. Accordingly, primates and humans are always in potential conflict over crops due to primates' renowned crop raiding behavior. Among wild animal species that cause damage to farmers' yield and trigger HWC, primates take the top ranking [12]. The genera Cercopithicus, Papio and Macaca, particularly baboons and grivet monkeys are some of the most serious crop raiders because of their intelligence, adaptability, wide dietary range, complex social organization and aggression [6]. As human populations expand and natural habitats shrink, people and animals are increasingly coming into conflict over living space and food. Although feeding on cereal crops increases

foraging efficiency and nutrient intake for primates, it is nuisance for farmers due to crop loss $[13,14]$.

Grivet monkeys (Cercopithecus aethiops) are slender agile Old World monkeys of the genus Cercopithecus, inhabiting wooded regions of Africa and the most widely distributed of the guenon species, occur from Ethiopia to Senegal and from Sudan to South Africa [15]. So far, this species is considered to be a widely distributed and often common species in northern and central Ethiopia in altitude ranging from near sea level to approximately $3000 \mathrm{~m}$ a.s.l. [16]. However, because of habitat fragmentation for human settlement and cultivated land into previous wildlife habitats, the distribution of grivet monkey is highly challenging nowadays. In many areas, this monkey frequents human settlements and feeds extensively on crops [16-18], which exacerbate the conflict with humans.

Longitudinal studies on conservation threats of primates are an important step towards developing effective conservation management plan. In spite of this governing rational, only a few studies have been conducted in central highlands of Ethiopia where the conflict is severe due to a high rate of forest degradation and restriction of primates to patches of habitat surrounded by agricultural fields [17]. This study aimed to provide baseline information on current situation of human-grivet monkey conflict (HGMC) and the perceptions of communities towards this monkey conservation. The researcher predicted that HGMC did not vary with regard to the distance of farmland from the forest boundary. The researcher also predicted that the attitude of households may not vary depending on the gender.

\section{Results}

\section{Demographic Characteristics and Socioeconomic profile of the Respondents}

A total of 143 individuals participated for questionnaire survey (Table 1). The majority of respondents $59.4 \%(n=85)$ were males, while $40.6 \%(n=58)$ were females. There was no significant difference in the proportion of genders interviewed among villages $(\chi 2=6.74, d f=5, p=0.24)$. Most of the respondents 81.1\% $(n=116)$ were married. Regarding educational level, most $83.9 \%(n=120)$ were literate, and the rest $16.1 \%(n=23)$ were uneducated. The family sizes of the respondents ranged from 1 to 11 with a mean of 
$4.82 \pm 2.13$. From the total respondent, $52.4 \%(n=75)$ possess family size of 4 to 6 individuals. There was significant difference in family size among villages $(\chi 2=21.82, d f=10, p=0.016)$. Among the households, $53.1 \%(n=75)$ possess $0.5-1$ ha of farmland while few $17.5 \%(n=25)$ possess $>1$ ha of farmland. There was significant difference among villages regarding farmland size $(\chi 2=19.52, d f=10, p$ $=0.034)$. The majority of respondents $84.6 \%(n=121)$ lack neither private nor communal grazing land and leave their cattle in the forest while only $11.9 \%(n=17)$ possess private grazing land. There was significant difference in the proportion of households owning grazing land (One sample T test: $t=59.6, \mathrm{df}$ $=142, p=0.000)$. However, there was no significant difference in the proportion of households owning grazing land among villages $(\chi 2=11.98, d f=10, p=0.29)$. The livelihoods of all respondents were subsistence farming where they reared livestock and cultivated different crops like barley (Hordeum vulgare L.), wheat (Triticum aestivum L.), bean (Vicia faba L.), maize (Zea mays), pea (Pisum sativum L.), and lentil (Lens culinaris Medikus).

Table 1. Demographic characteristics and socioeconomic profile of respondents around Wof-Washa Natural State Forest 


\begin{tabular}{|c|c|c|c|}
\hline characteristics & Category & N (frequency) & $\%$ (percent) \\
\hline \multirow[t]{4}{*}{ Age } & $18-30$ & 41 & 28.7 \\
\hline & $31-43$ & 48 & 33.6 \\
\hline & $44-56$ & 31 & 21.7 \\
\hline & $>57$ & 23 & 16.1 \\
\hline \multirow[t]{2}{*}{ Sex } & Male & 85 & 59.4 \\
\hline & Female & 58 & 40.6 \\
\hline \multirow[t]{2}{*}{ Marital Status } & Married & 116 & 81.1 \\
\hline & Single & 27 & 18.9 \\
\hline \multirow[t]{4}{*}{ Education } & Uneducated & 23 & 16.1 \\
\hline & informal education & 48 & 33.6 \\
\hline & primary & 50 & 35.0 \\
\hline & secondary & 22 & 15.4 \\
\hline \multirow[t]{3}{*}{ Family size } & $1-3$ & 36 & 25.2 \\
\hline & $4-6$ & 75 & 52.4 \\
\hline & $>7$ & 32 & 22.4 \\
\hline \multirow[t]{2}{*}{ Source of livelihood } & Crop cultivation & 5 & 3.5 \\
\hline & Crop \& livestock & 138 & 96.5 \\
\hline \multirow[t]{3}{*}{ Farmland size } & $<0.5$ ha & 42 & 29.4 \\
\hline & $0.5-1$ ha & 76 & 53.1 \\
\hline & $>1$ ha & 25 & 17.5 \\
\hline \multirow[t]{4}{*}{ Number of livestock } & $0-5$ & 25 & 17.5 \\
\hline & $5-10$ & 78 & 54.5 \\
\hline & 15-Nov & 36 & 25.2 \\
\hline & $>15$ & 4 & 2.8 \\
\hline \multirow[t]{3}{*}{ Grazing land } & No, in barn & 5 & 3.5 \\
\hline & Yes, private & 17 & 11.9 \\
\hline & No, in the forest & 121 & 84.6 \\
\hline
\end{tabular}




\section{Human-grivet monkey conflict}

Based on the questionnaire survey, the common crop raiders in WWNSF in their ranking order were grivet monkeys (47.6\%), bushbuck (37.8\%), gelada (5.6\%), porcupine (4.2\%), rabbit $(2.8 \%)$ and duiker $(2.1 \%)$, where grivet monkeys were the most intensive. Accordingly, the majority of respondents from both gender (male $=67.1 \%$; female $=74.1 \%$ ) were not supporting grivet monkey conservation indicating that they have negative attitude to the monkey. More male (32.9\%) respondents were interested to the conservation of grivet monkey as compared with females (20.7\%). Pearson's Chi-Square test showed that there was significant difference between genders regarding their interest to grivet monkey conservation $(\chi 2=6.49$, df $=2, P=0.04$ ) (Table 2). There were no statistical difference in respondents' perceptions to grivet monkey conservation based on their marital status, education status and family size. Village of households and their cropland distance from the forest had significant impact on their perception of respondents towards supporting grivet monkey conservation. Majority of respondents $(77.8 \%)$ having farmland $401 \mathrm{~m}$ away from the forest supported the importance of grivet monkey conservation while those nearer to the forest argued against the issue. There was significant difference in respondents perceptions towards grivet monkey conservation based on distance of farmland from the forest $(\chi 2=12.7, \mathrm{df}=4, \mathrm{P}=0.013)$ (Table 2). Respondents who argued grivet monkey conservation claimed several problems like damage to field crops, gardens, theft of backyard resources, children absenteeism from schooling, and extra workload of crop guarding which interrupt other socioeconomic activities. On the other hand, respondents those supported grivet monkey conservation stated that the monkeys are source of happiness, tourist attraction, heritage to the country and the generations to come.

Table 2 Community perceptions towards grivet monkey conservation around WWNSF 


\begin{tabular}{|c|c|c|c|c|c|c|c|}
\hline \multirow[b]{2}{*}{ variables } & \multirow[b]{2}{*}{ Categories } & \multicolumn{6}{|c|}{ Is conserving grivet monkey important? } \\
\hline & & $\begin{array}{l}\text { Important } \\
(\%)\end{array}$ & $\begin{array}{l}\text { Not } \\
\text { important } \\
(\%)\end{array}$ & $\begin{array}{l}\text { I do not } \\
\text { know (\%) }\end{array}$ & $x^{2}$ & df & $\begin{array}{l}\mathrm{p} \\
\text { value }\end{array}$ \\
\hline \multirow[t]{2}{*}{ sex } & male & 32.9 & 67.1 & 0.0 & 6.49 & 2 & 0.04 \\
\hline & female & 20.7 & 74.1 & 5.2 & & & \\
\hline \multirow[t]{4}{*}{ age } & $18-30$ & 24.4 & 75.6 & 0.0 & 13.23 & 6 & 0.04 \\
\hline & $31-43$ & 25.0 & 75.0 & 0.0 & & & \\
\hline & $44-56$ & 35.5 & 54.8 & 9.7 & & & \\
\hline & $>56$ & 30.4 & 69.6 & 0.0 & & & \\
\hline \multirow[t]{2}{*}{ Marital status } & married & 25.9 & 71.6 & 2.6 & 1.91 & 2 & 0.39 \\
\hline & single & 37.0 & 63.0 & 0.0 & & & \\
\hline \multirow{4}{*}{$\begin{array}{l}\text { Educational } \\
\text { status }\end{array}$} & Uneducated & 21.7 & 73.9 & 4.3 & 3.53 & 6 & 0.74 \\
\hline & $\begin{array}{l}\text { informal } \\
\text { education }\end{array}$ & 25.0 & 75.0 & 0.0 & & & \\
\hline & primary & 32.0 & 66.0 & 2.0 & & & \\
\hline & secondary & 31.8 & 63.6 & 4.5 & & & \\
\hline \multirow{3}{*}{$\begin{array}{l}\text { Distance from } \\
\text { forest }(m)\end{array}$} & $<200$ & 24.5 & 72.6 & 2.8 & 12.7 & 4 & 0.013 \\
\hline & $201-400$ & 25 & 75 & 0.0 & & & \\
\hline & $>401$ & 77.8 & 22.2 & 0.0 & & & \\
\hline \multirow[t]{3}{*}{ Family size } & $1-3$ & 36.1 & 63.9 & 0.0 & 7 & 4 & 0.13 \\
\hline & $4-6$ & 20.0 & 76.0 & 4.0 & & & \\
\hline & $>7$ & 37.5 & 62.5 & 0.0 & & & \\
\hline \multirow[t]{6}{*}{ Village } & Chachahudad & 41.2 & 58.8 & 0.0 & 22 & 10 & $0 . .013$ \\
\hline & $\begin{array}{l}\text { Giderach- } \\
\text { Lankuso }\end{array}$ & 13.6 & 86.4 & 0.0 & & & \\
\hline & Ayer & 8.0 & 92.0 & 0.0 & & & \\
\hline & $\begin{array}{l}\text { Silasie } \\
\text { Gedam }\end{array}$ & 38.7 & 58.1 & 3.2 & & & \\
\hline & Mebreka`mba & 42.1 & 47.4 & 10.5 & & & \\
\hline & Gifte & 27.6 & 72.4 & 0.0 & & & \\
\hline
\end{tabular}


Among the various techniques (guarding by dog, guarding and scare away by humans, scarecrow and killing by trap) (Plate 1a-d) used to prevent crop raiding by grivet monkeys, $51.3 \% \pm$ SD $15.2(n=74)$ of respondents used to scare away grivets by human (Table 3). Although, killing was the least (7.2 \pm SD 2.5) used technique, it has been used to kill animals for two reasons : 1) reduce the number 2) to chase away troops of grivet monkey and discourage further crop raiding by using the dead animals as scarecrow (Plate 1d). There was no significant difference in the techniques used by villagers to alleviate crop raiding by grivet monkeys $(X 2=14.73, d f=15, P=0.47$ ) (Table 2 ). Guarding using dog was the second effective technique where farmers either accompanied dogs with them or tied dogs at the periphery of farmland to be used as warning to grivet monkeys and as alarm for farmers (Plate 1a). Guarding and scare away by humans includes taking watch in the farmland field, chasing grivet monkey back to the forest, shouting and scaring and slingshots to scare the animals. Females and children are the most responsible family members to guard crop fields against crop raiders.

Table 3. Techniques used by respondents to prevent crop damage by grivet monkey around WWNSF

\begin{tabular}{|lllll|}
\hline \multicolumn{5}{|l}{ method of crop protection } \\
village & $\begin{array}{l}\text { guarding by } \\
\text { dog }\end{array}$ & $\begin{array}{l}\text { Guarding \& scare away by } \\
\text { humans }\end{array}$ & Scarecrow & $\begin{array}{l}\text { killing by } \\
\text { trap }\end{array}$ \\
\hline Ghachahudad & 17.6 & 58.8 & 17.6 & 5.9 \\
\hline Ayer & 31.8 & 36.4 & 22.7 & 9.1 \\
\hline Silasie Gedam & 22.6 & 28.0 & 20.0 & 8.0 \\
\hline Mebrekamba & 15.8 & 54.5 & 6.5 & 6.5 \\
\hline Gifte & 24.1 & 62.1 & 15.8 & 10.5 \\
\hline Mean & 26.0 & 51.3 & 10.3 & 3.4 \\
\hline $\begin{array}{l}\text { Standard Deviation } \\
\text { (SD) }\end{array}$ & 10.5 & 15.2 & 15.5 & 7.2 \\
\hline
\end{tabular}

The respondents have expected stakeholders including government bodies to design alternative crop damage prevention methods and compensation of damage to loosen the uptight HGMC. The households revealed that they would be delighted if government took measures like compensation strategies, reduction of the number of grivet monkeys and relocation options. Majority of respondents $(56.3 \% \pm S D$ 23) claimed eradication/relocation of grivet monkeys followed by financial compensation (16.2 \pm SD 7.7) including exception of farmland taxation (Fig. 2). There was significant difference in respondents view on the mitigation measures to be taken by government $(\chi 2=40.01, d f=15, P=0.000)$. 
Respondents claimed that habitat degradation, proximity of crop land to forest, preferences of grivet monkey to crops, and degradation of food plants of grivet monkeys were the main causes of crop damage. On average $42.5 \pm$ SD 8.68 of respondents in all villages elucidated that the causes of crop damage by grivet monkey is triggered by habitat degradations (Table 3 ). Proximity of crop land to the forest was rated as the second reason for crop damage by grivet monkeys and associated conflict. There was no significant difference in respondents view on the causes of crop damage by grivet monkeys among villages $(X 2=6, d f=15, P=0.98)$.

Table 4. Respondents perception on the causes of crop damage by grivet monkeys around WWNSF

\begin{tabular}{|lllll|}
\hline Village & $\begin{array}{l}\text { Habitat } \\
\text { degradation }\end{array}$ & $\begin{array}{l}\text { preferences to } \\
\text { crop }\end{array}$ & $\begin{array}{l}\text { proximity of farmland to } \\
\text { forest }\end{array}$ & $\begin{array}{l}\text { food plants } \\
\text { degradation }\end{array}$ \\
\hline Chachahudad & 58.8 & 5.9 & 11.8 & 23.5 \\
\hline $\begin{array}{l}\text { Giderach- } \\
\text { Lankuso }\end{array}$ & 36.4 & 4.5 & 31.8 & 27.3 \\
\hline Ayer & 44.0 & 12.0 & 24.0 & 20.0 \\
\hline $\begin{array}{l}\text { Silasie } \\
\text { Gedam }\end{array}$ & 35.5 & 6.5 & 35.5 & 22.6 \\
\hline Mebrekamba & 42.1 & 5.3 & 31.6 & 21.1 \\
\hline Gifte & 37.9 & 10.3 & 31.0 & 20.7 \\
\hline Mean & 42.5 & 7.4 & 27.6 & 22.5 \\
\hline SD & 8.68 & 3.02 & 8.62 & 2.66 \\
\hline
\end{tabular}

Grivet monkeys have been impacted with ruthlessness human persecution as a consequence of crop raiding. Respondents chase, shot and trapped grivet monkeys as a revenge of their crop loss (Plate 2). Deforestation, livestock grazing, wood collection for firewood and sale, and agricultural encroachments are becoming common and widespread practices in the study area. Residents around WWNF usually cut trees such as Hagenia abyssinica, Prunus Africana, Olea europaea cuspidata, Olinia rochetiana, Ficus sur, Dombeya torrid, Myrica salcifolia, Allophylus abyssinicus, Ekebergia capensis, Podocarpus falcatus, Juniperus procera, Maesa lanceolata, Ilex mitis, Celtis Africana and others for purposes like house construction, firewood, timbering, animal fodder, fencing and household and farming utensils (Table 5), most of which used as food sources for grivet monkeys. Such overlapping of human goals with the needs of grivet further escalates the conflict and endangers grivet monkey conservation in the study area.

Table 5. Tree species logged by local communities around WWNF for different purpose 


\begin{tabular}{|c|c|c|c|c|c|}
\hline & & Forest product utilizati & & & \\
\hline Local name & tree species & $\begin{array}{l}\text { timbering for house \& } \\
\text { utensil construction }\end{array}$ & $\begin{array}{l}\text { fuel } \\
\text { wood }\end{array}$ & $\begin{array}{l}\text { animal } \\
\text { fodder }\end{array}$ & Fencing \\
\hline Zigba & $\begin{array}{l}\text { Podocarpus } \\
\text { falcatus }\end{array}$ & $\sqrt{ }$ & $\sqrt{ }$ & & \\
\hline Tsid & $\begin{array}{l}\text { Juniperus } \\
\text { procera }\end{array}$ & $\sqrt{ }$ & & & $\sqrt{ }$ \\
\hline Zingerowonber & Polyscias fulva & $\sqrt{ }$ & & & \\
\hline Misargenfo & Ilex mitis & & & $\sqrt{ }$ & \\
\hline Weira & Olea europaea & $\sqrt{ }$ & $\sqrt{ }$ & $\sqrt{ }$ & \\
\hline Kelewa & $\begin{array}{l}\text { Maesa } \\
\text { lanceolata }\end{array}$ & & $\sqrt{ }$ & & $\sqrt{ }$ \\
\hline Weyel & $\begin{array}{l}\text { Pittasporum } \\
\text { viridifforum }\end{array}$ & $\sqrt{ }$ & $\sqrt{ }$ & $\sqrt{ }$ & $\sqrt{ }$ \\
\hline Kosso & $\begin{array}{l}\text { Hygenia } \\
\text { abyssinica }\end{array}$ & $\sqrt{ }$ & & $\sqrt{ }$ & \\
\hline Tifie & Olinia rochetiana & $\sqrt{ }$ & $\sqrt{ }$ & $\sqrt{ }$ & $\sqrt{ }$ \\
\hline Ameja & $\begin{array}{l}\text { Hypericum } \\
\text { revolutum }\end{array}$ & & $\sqrt{ }$ & $\sqrt{ }$ & \\
\hline Shola & Ficus Sur & & & & \\
\hline Wulkifa & Dombeya torrida & & & $\sqrt{ }$ & \\
\hline Azamir & $\begin{array}{l}\text { Bersama } \\
\text { abyssinica }\end{array}$ & & $\sqrt{ }$ & & \\
\hline Kewot & Celtis Africana & & $\sqrt{ }$ & & \\
\hline Lanquso & $\begin{array}{l}\text { Urera } \\
\text { hypselodendron }\end{array}$ & & & & \\
\hline totakula & $\begin{array}{l}\text { Galiniera } \\
\text { saxifraga }\end{array}$ & $\sqrt{ }$ & $\sqrt{ }$ & $\sqrt{ }$ & \\
\hline Embus & $\begin{array}{l}\text { Allophylus } \\
\text { abyssinica }\end{array}$ & & $\sqrt{ }$ & & \\
\hline Kechemo & Myrsine africana & & & $\sqrt{ }$ & $\sqrt{ }$ \\
\hline
\end{tabular}


In recent decades, human population growth and the related expansion of agricultural and industrial activities have intensified HWCs $[19,20]$. In the developing countries like Ethiopia, the livelihoods of most of the peoples living in the rural area are depended on livestock holdings and agriculture which made HWC the most intensive [3]. Recently, HWC undoubtedly ranks amongst the main threats to conservation of wildlife in Africa [12]. This study also revealed that the communities around WWNSF experienced intensive conflict with grivet monkeys over crops. The livelihoods of all communities in the study area were subsistence farming where they reared livestock and cultivated different crops on small land size [17]. Among the households, $53.1 \%$ possess $0.5-1$ ha of farmland while about $17.5 \%$ possess $>1$ ha of farmland where they produce crops like Hordeum vulgare L., Triticum aestivum L., Vicia faba L., Zea mays, Pisum sativum L., Lens culinaris Medikus. Similar result have been reported by [19] where most of the respondents produce a limited number of crops on a plots of land. The attitudes of respondents to the conservation of grivet monkeys were negative and differences were observed with reference to gender, distance from the forest and village/localities of cropland relative to the forest.

The present study revealed that human grivet monkeys' conflict is a customary interaction within the WWNSF boundary. In spite of several factors causing human primate conflict, crop raiding is the frontline reason that becomes heightened during the months from sowing crops to harvesting. Respondents having cropland closer to the forest area had negative attitudes towards grivet monkey conservation due to greater incidence of damage to their crops, replicating the trend of crop damage reported from earlier studies $[2,10,14,17,21]$. Respondents are pleased to chase out the monkeys from the periphery of the forest facing the cropland. This is contrary to the thought that resolving HWC lies on evading wildlife attractions to human habitation instead of getting rid of monkeys, which indeed requires a change in human habits, entrenched ways of thinking and the expenditure of public and private resources [22].

Households around WWNSF prevent crop damage against grivet monkeys by guarding their crop land using scarecrows including carcass of killed grivet monkey [10], dogs, children and females vigilance, and even trapping animals. Over $76.3 \%$ of respondents used guarding ( $51.3 \%$ by human and $26 \%$ by dogs) to deter grivet monkey against crop damage while other methods were preferred by less proportion of the respondents. Other studies revealed that guarding is the most effective and commonly used method to prevent crop raiding from crop raiders $[2,10,19,21,23]$. Killing was the least effective method in this study area where the action is forbidden by the law of the country to protect the wildlife from mass persecutions. Moreover, scarecrow was ineffective to deter crop grivet monkeys from crop damages as the animals habituated the symbol and become non-responsive after a certain timeframe. The result was agreed with [13] who reported that the effect of scarecrow in preventing crop damage by wildlife is temporary.

Crop-raiding by wildlife like grivet monkeys perceived as a significant problem causing a serious hazard to the food security and livelihoods of smallholder farmers' households [21], which leads households to develop negative attitude and resentful attack on primates. Understanding the attitude of local communities towards wildlife is very crucial to attain long term success of conservation endeavor [24]. The questionnaire survey revealed that, the anticipated perceptions of respondents to tackle HGMC in 
WWNSF were eradication/relocation of grivet monkey followed by financial compensation. Moreover, they would be very thrilled if government bodies intervene to reduce the population size of the animals by killing. Similarly, [21] reported that relocation and killing of problematic wildlife were the actions that households recommend to combat HWC that they experienced in Ngangao forest, Kenya. Studies revealed that the negative impact and resources damage posed by wildlife are the priority area that need to be reduced by developing mitigation measures, accurate and reasonable verification of damages, and compensation schemes to economic impacts [25].

Respondents revealed that the main cause of crop damage by grivet monkey in WWNSF was triggered by habitat degradations. Local communities were encroached to the forest to collect wood for sale, fuel wood and cut trees used for animal fodder, and made household and agricultural utensils from the forest. This finding is similar to studies conducted on red-tailed monkeys in Uganda [26] and on grivet monkey in Batiero Church forest, Ethiopia [17], inferring that conversion of forest for agricultural farmlands and other purposes lead many nonhuman primates to concentrate on crops as their main source of food. Respondents less considered the impact of grivet monkey preference on crops to be a reason for crop raiding. In line with this finding, [9] in Lake Nabugabo, Uganda, reported that nutritionally anthropogenic and wild food are similar. However, [17] in Batiero Church forest, Ethiopia, reported that human-primate conflicts were intensified during crop maturity and harvesting stages when grivet monkeys had preference to feed on the crops which differed from this result. This might be due to patchiness, degradation and lower quality of the habitat in Batiero Church forest where reduction in the availability of natural food sources leads the animals seeking alternate food sources [23]. Accordingly, human expansion into natural habitats worldwide has been the root of the hot conflict between wildlife and humans where natural food sources of wildlife are replaced by anthropogenic ones [22].

\section{Conclusion}

The finding of this study revealed that there was a strong conflict between human and grivet monkeys in and around WWNSF. This study, therefore, provides baseline data on crop damage for developing feasible wildlife management plan to enable friendly long-term coexistence of local communities with grivet monkey and other wildlife in and around WWNSF. Because crop-raiding by wildlife including grivet monkeys is the main cause that leads local communities develop negative attitudes and engaged in revengeful killing of wildlife to exterminate locally. Hence, grivet monkeys have been impacted with ruthlessness human persecution as a consequence of crop raiding. Forest alteration into agricultural lands and degradation due to cutting of trees for sale and firewood represents the most detrimental human activity that trigger HWC. Mitigation measures of HGMC need to focus on techniques that would not result in local extermination of grivet monkey population rather simply deter these animals in such a way that they stay in the forests, their natural home. Farmers also need to be encouraged to shift their crops productions which are unpalatable to grivet monkeys. More education can be launched to create awareness among local communities on the importance of wildlife and create job opportunities to reduce unemployment to mitigate the pressure of local people on wildlife and the forest. 


\section{Methods}

\section{Description of the study area}

The study on HGMC and community perception to crop lose by grivet monkey (Cercopithecus aethiopes aethiops) was conducted in and around Wof-Washa Natural State Forest (WWNSF), which is located in North Shoa Zonal administration, Amhara National Regional State, Northwestern highlands of Ethiopia. The study area extends approximately between $9^{\circ} 42^{\prime}-9^{\circ} 47^{\prime} \mathrm{N}$ latitudes and between $39^{\circ} 43^{\prime}-39^{\circ} 49^{\prime} \mathrm{E}$ longitudes (Fig. 1). Topographically, the forest is situated along the altitudinal gradient between 1,650 $\mathrm{m}$ asl near Gift Michael where it merges into Acacia scrubland on the valley floor to 3,700 $\mathrm{m}$ asl at the top of the Rift Valley escarpment near Kundi on the plateau ridge.

The long history of settlement and cultivation coupled with deforestation and cattle grazing have led to intense pressure on the land, decreased soil quality, soil erosion and deforestation. Beyond the hillsides are mostly very steep and hard to cultivate, plot sizes are commonly very small with an average land holding 1.5 ha in Amahara Region [27].

The main characteristic plant species at the higher altitudes are Hagenia abyssinica, Olea europaea cuspidata and Juniperus procera. Podocarpus falcatus, Allophylus abyssinicus, Haleria lucida, Euphorbia abyssinica, Polyscias fulva and Olinia rochetiana at the middle. Above 3,000 m Erica arborea, Hypericum revolutum and giant Lobelia spp. are the most dominant species with few Hagenia abyssinica and Pittosporium viridiflorum below inaccessible cliffy and steep slope areas. Generally, there are over 394 species of plants, of which, 46 species $(12 \%)$ are endemic to Ethiopia while $7(2 \%)$ are nearly endemic [28, 29].

\section{Data collection}

In order to evaluate the perceptions of farmers on crop damage by grivet monkey, the researcher surveyed villagers living around WWNSF from August 2017 to June 2018. Questionnaire surveys were administered for 143 households in six grivet monkey localities near WWNSF (Ayer, Chachahudad, Giderach-Lanquso, Silasie Gedam, Mebreqamba and Gifte). These households were randomly selected by following a pattern of skipping one household, and the second household interviewed. The survey questionnaires were administered to farmers within their farming area or residence by the researcher and field assistants [30]. Questionnaires included both open and close-ended questions to get information about communities' perceptions on HGMC, their socioeconomic situation, measures they took to mitigate losses, attitudes to grivet conservation. A single person aged 18 years was taken to represent a household and the average interview session per sampled household was 25-35 min.

\section{Data analysis}

Data were analyzed using Statistical Package for Social Sciences (SPSS) software version 25. Descriptive statics and Pearson Chi-Square test had been used to analyze the data. Chi-square test was used to determine the significant differences among villages with regard to perceptions to crop damage 
by grivet monkeys, techniques used in protecting crop damage, attitudes towards conservation of grivet monkeys. All statistical tests were two-tailed with $95 \%$ confidence intervals and level of rejection set at $\mathrm{P}=0.05$.

\section{Ethical statement}

The study was approved by Debre Berhan University, college of Natural and Computational Sciences, Department of Biology, Ethiopia. Permission was obtained from the Ethiopian Wildlife Conservation Authority and Tarmaber Woreda administration office. The researcher contacted participants of the study in face to face and informed them the purpose of the study in their mother tongue and assured about confidentiality of their say before, during and after the research. Participants were assured of anonymity and that information would be used for the study in question. Informed consent was obtained from study participants before the commencement of each questionnaire. The participants were granted that withdraw from the questionnaire and discussion at any time had no risk.

\section{Declarations}

\section{Acknowledgments}

I would like to thank Debre Berhan University for facilities support. This research was also supported by grants from Primate Conservation, Incorporated (PCI) (Grant No. PCI\# 1230) and IDEA WILD for field material support. I would like to offer my sincere thanks to WWNSF office members, scouts and local communities for their hospitality and kind response for sharing their in depth knowledge to pursue this research. I would also like to thank local field assistants: Lema Mamuye, Biruk Shewayirga, Wondosen Getahun, Mamuye Gizaw,

\section{Authors' contributions}

DY proposed the research idea and collected the data from the respondents, organized and analyzed the data, interpreted the findings, and wrote the manuscript.

\section{Funding}

The research work was funded by Primate Conservation, Incorporated (PCl) (Grant No. PCl\# 1230) and IDEA WILD (equipment support). The role of funding organizations is financing the research and support materials and hence not involved in the design of the study, collection, analysis, and interpretation of data and in manuscript write up.

\section{Availability of data and materials}

The data used and analyzed during the current study is available from the corresponding author on a reasonable request, without disclosure of the respondents.

\section{Ethics approval and consent to participate}


The methods were carried out in accordance with the relevant guidelines and regulations of Ethiopian Wildlife Conservation Authority. Permission was granted by the Ethiopian Wildlife Conservation Authority to conduct the research. This research adhered to the ethical and legal requirements of the American Society of Primatologists Principles for the Ethical Treatment of Non-Human Primates. Moreover, informed consent was obtained from all participants before the commencement of the study.

\section{Consent for publication}

This manuscript does not contain any individual person's data, and further consent for publication is not required/ applicable.

\section{Competing interests}

I declare that there are no competing interests to declare, because the research is solely my own work.

\section{Author details}

Affiliation: Debre Berhan University, College of Natural and Computational Science, Department of Biology, P.O. Box 445, Debre Berhan, Ethiopia

Research area: Ecology and systematic Zoology, wildlife management, primatology

\section{Abbreviations}

GPS: Global Positioning System; HGMC: Human Grivet Monkey Conflict; HWC: Human Wildlife Conflict; SD: standard Deviation; SPSS: Statistical Package for Social Sciences; WWNSF: Wof-Washa Natural State Forest

\section{References}

1. Nyhus P, Fischer H, Madden F, Osofsky S. Taking the bite out of wildlife damage: The challenges of wildlife compensation schemes. Conserv Pract. 2003; 4:37-43.

2. Merkebu S, Yazezew D. Assessment of Human-Wildlife Conflict and the Attitude of Local Communities to Wild Animal Conservation around Borena Sayint National Park, Ethiopia. Int J Ecol. 2021; 2021:6619757.

3. Anand S, Radhakrishna S. Investigating trends in human-wildlife conflict: is conflict escalation real or imagined? J Asia-Pac Biodiver. 2017; 10:154-161.

4. Madden F. Creating coexistence between humans and wildlife: Global perspectives on local efforts to address human-wildlife conflict. Hum Dimens Wildl. 2004; 9:247-257. 
5. Fernanda M, Carlos AP. Anthropogenic determinants of primate and carnivore local extinctions in a fragmented forest landscape of southern Amazonia. Biol Conserv. 2005; 124 383-396.

6. Sillero-Zubiri C, Swetzer D. Crop Raiding Primate: searching for alternative, human ways to resolve conflict with farmer in Africa. Oxford, United Kingdom: Oxford University; 2001.

7. Cowlishaw G, Dunbar RI. Primate conservation biology. Chicago: University of Chicago Press; 2000.

8. Strum SC. The Development of Primate Raiding: Implications for Management and Conservation. Int J Primatol. 2010; 31:133-156.

9. Cancelliere EC, Chapman CA, Twinomugisha D, Rothman JM. The nutritional value of feeding on crops: Diets of vervet monkeys in a humanized landscape. Afr J Ecol. 2018; 00:1-8

10. Saj TL, Sicotte P, Paterson JD. The conflict between vervet monkeys and farmers at the forest edge in Entebbe, Uganda. Afr J Ecol. 2001; 39:195-199.

11. Fufa D, Yazezew D, Degefe G, Gebrehiwot S. Abundance, Diversity, and Distribution of Primates at Welel Mountain, Kellem Wollega Zone, Oromia Region, Ethiopia. Sci Worl J. 2020; 2020.

12. Wiafe ED. Primates crop raiding situation on farmlands adjacent to South-West of Mole National Park, Ghana. Ghan J Agric Sci. 2019; 54(2):58-67.

13. Kifle Z, Bekele A. Human-Gelada Conflict and Attitude of the Local Community toward the Conservation of the Southern Gelada (Theropithecus gelada obscurus) around Borena Saynit National Park, Ethiopia. Environ Manage. 2020; 65(3):399-409.

14. Naughton-Treves L. Predicting patterns of crop damage by wildlife around Kibale National Park, Uganda. Conserv Biol. 1998; 12(1):156-168.

15. Shimada MK, Shishotake T. Genetic variation of blood proteins within and between local populations of Grivet monkey in Central Ethiopia. Primates,. 1997; 38(4):399-414.

16. Yalden D, Largenc M, Kock D. Catalogue of the mammals of Ethiopia: 3. Primates: pubblicazioni del centro di studio per la faunistica ed ecologia tropicali del cnr: CXXII. Monit Zool Ital Suppl. 1977; $9(1): 1-52$.

17. Alelign A, Yonas M. Community perceptions of grivet monkey crop depredation in the Ethiopian Highlands implications for primate conservation. Hum Wildl Interac 2017; 11(2):175-181.

18. Zinner D, Pelaez F, Torkler F. Distribution and habitat of grivet monkeys (Cercopithecus aethiops aethiops) in eastern and central Eritrea. Afr J Ecol. 2002; 40:151-158. 
19. Yitayih Y, Ejigu D, Mola M. Population size and human-grivet monkeys (Chlorocebus aethiops) conflict in Zegie peninsula, Bahir Dar, Ethiopia. BMC Zool. 2021; 6:2.

20. Ndava J, Nyika EH. Human-Baboon Conflict on Resettled Farms in Zimbabwe: Attitudes and Perceptions among local farmers. Curr J Appl Sci Technol. 2019; 33(1):1-10.

21. Siljander M, Kuronen T, Johansson T, Munyao MN, Petri K, Pellikka E. Primates on the farm spatial patterns of human-wildlife conflict in forest-agricultural landscape mosaic in Taita Hills, Kenya. Appl Geopgr. 2020; 117:1-13.

22. Dittus W, Gunathilakec S, Felder M. Assessing Public Perceptions and Solutions to HumanMonkey Conflict from 50 Years in Sri Lanka. Folia Primatol. 2019; 90:89-108.

23. Mekonnen S. Coexistence between human and wildlife: the nature, causes and mitigations of human wildlife confict around Bale Mountains National Park, Southeast Ethiopia. BMC Ecol. 2020; 20:51.

24. Eshete M, Lilieholm RJ, Ashenafi ZT, LeaderWilliams N. Community attitudes toward wildlife and protected area in Ethiopia. . Soc Nat Resour. 2010; 23:489-506.

25. Barua M, Bhagwat AS, Jadhav S. The hidden dimensions of human-wildlife conflict: Health impacts, opportunity and transaction costs. Biol Conserv. 2013; 157:309-316.

26. Baranga D, Isabirye BG, Teichroeb JA, Chapman CA. Crop raiding patterns of solitary and social groups of red-tailed monkeys on cocoa pods in Uganda. Trop Conserv Sci. 2012; 5:104-111.

27. Veronika S. wof washa - cave of bird Dynamics of a Forest at the Eastern Escarpment of the Ethiopian Highlands. Diploma. Zurich: University of Zurich; 2008.

28. Teketay D, Bekele T. Floristic composition of Wof-Washa natural forest, Central Ethiopia: Implications for the conservation of biodiversity. . Fed Reperto. 1995; 106:127-147.

29. Tilahun A. Vegetation Ecology and Carbon Stock of Wof-Washa Forest, North Shewa Zone, Amhara Region, Ethiopia. PhD. Addis Ababa: Addis Ababa University; 2018.

30. Hill CM. Conflict of Interest between People and Baboons: Crop Raiding in Uganda. . Int J Primatol. 2000; 2:299-315.

\section{Figures}




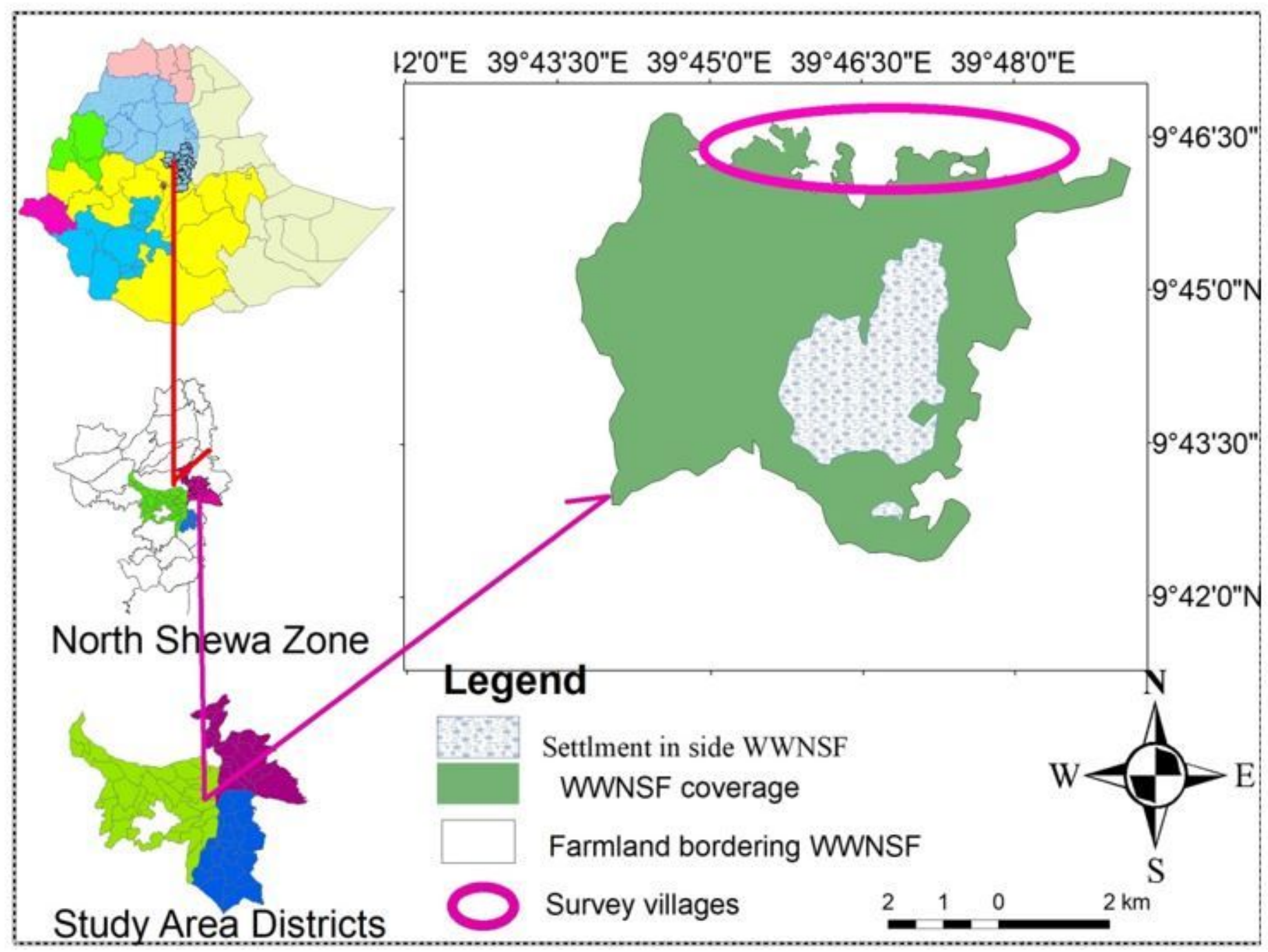

Figure 1

Map of the WWNSF 


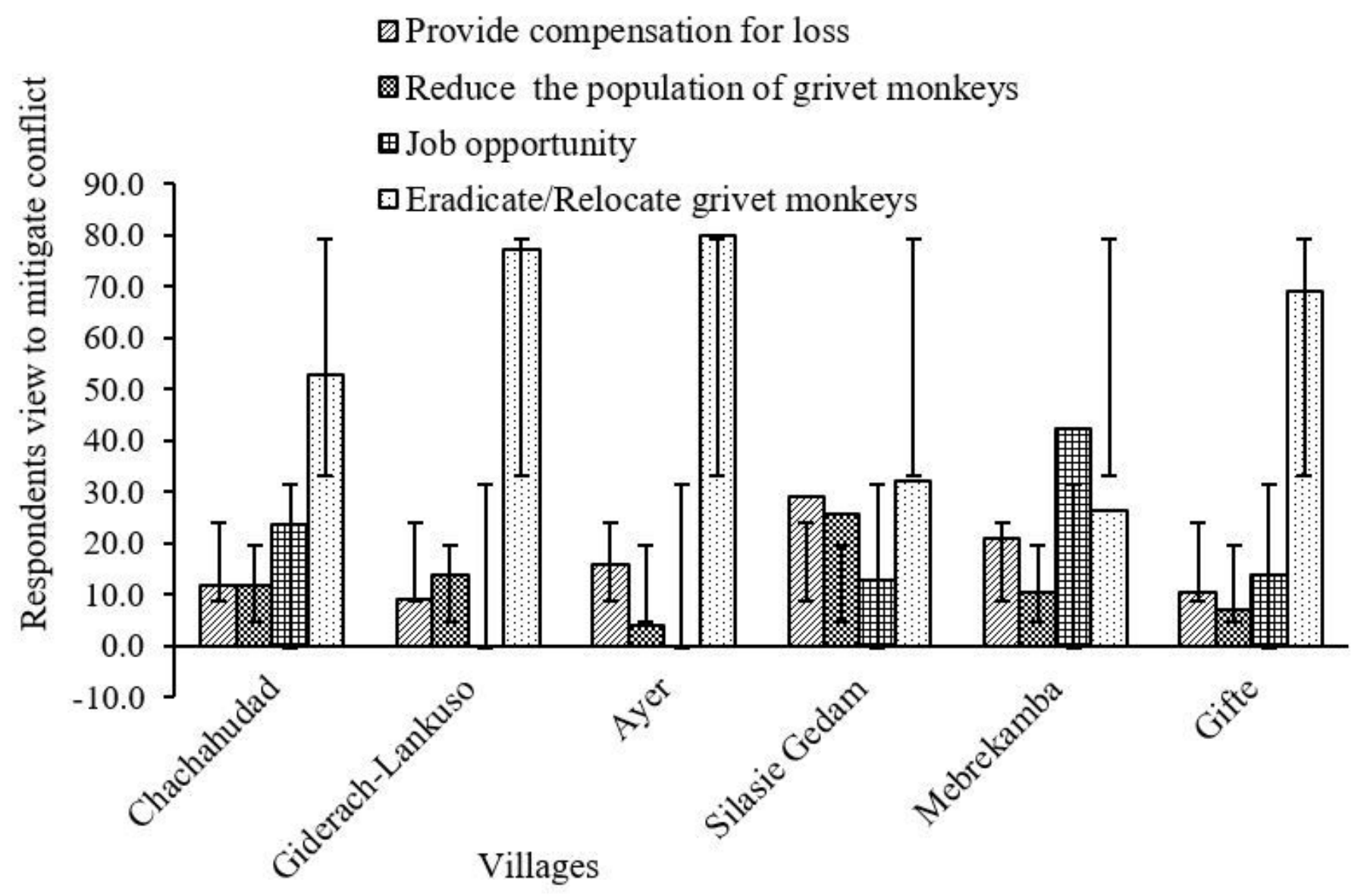

Figure 2

Respondents opinion on the options to be taken by the government and other stakeholders

\section{Supplementary Files}

This is a list of supplementary files associated with this preprint. Click to download.

- si2.jpg

- si1.jpg 